\title{
Pengaruh Model Pembelajaran Kooperatif Tipe Group Investigation (GI) Berbasis Lesson Study Terhadap Penguasaan Konsep IPA
}

\author{
P.G. N. Putra' ${ }^{1}$, I G. Margunayasa ${ }^{2}$, I M. C. Wibawa ${ }^{3}$ \\ ${ }^{123}$ Jurusan Pendidikan Guru Sekolah Dasar \\ UniversitasPendidikan Ganesha \\ Singaraja, Indonesia \\ e-mail: ${ }^{1}$ nanggputra27@gmail.com, ${ }^{2}$ igede.margunayasa@undiksha.ac.id, \\ imadecitra.wibawa@undiksha.ac.id
}

\begin{abstract}
Abstrak
Penelitian ini bertujuan untuk mengetahui perbedaan penguasaan konsep IPA antara siswa kelas IV semester II yang menerapkan model pembelajaran kooperatif group investigation dengan siswa kelas IV semester II yang menerapkan pembelajaran konvensional di SD Gugus XIV Kecamatan Buleleng Tahun Pelajaran 2017/2018. Penelitian ini merupakan eksperimen semu danmenggunakan rancangan non-equivalent post-test only control group design. Berdasarkan hasil dari pelaksanaan penelitian diperoleh hasil rata-rata kelompok ekperimen sebesar 22,71, sedangkan pada kelompok kontrol memperoleh rata-rata skor sebesar 13,92. Berdasarkan kategori data penguasaan konsep IPA diketahui bahwa data penguasaan konsep IPA pada kelompok eksperimen termasuk ke dalam kategori sangat tinggi, sedangkan data penguasaan konsep IPA kelompok kontrol termasuk ke dalam kategori sedang. Berdasarkan analisis diperoleh $t_{\text {hitung }}=7,402$, dan $t_{\text {tabel }}=2,021$. Hal ini menunjukkan bahwa terdapat perbedaan penguasaan konsep IPA antara siswa kelas IV semester II yang menerapkan model pembelajaran kooperatif group investigation dengan siswa kelas IV semester II yang menerapkan pembelajaran konvensional di SD Gugus XIV Kecamatan Buleleng Tahun Pelajaran 2017/2018.
\end{abstract}

Kata Kunci: Peningkatan group investigation, penguasaan konsep, IPA

\begin{abstract}
The research aimed to determine the difference of mastery of science concept between students who had been taught with group investigation learning model based with lesson study and students with conventional learning in the fifth-grade students Cluster XIV District of Buleleng in academic year 2017/2018. This research was quasi-experimental design and used non-equivalent post-test only control group design. Based on the result of research gained average score of experimental group amount 22,71, while in control group gained average score amount 13,92. Based on data category mastery of science concept noted that data mastery of science concept in experimental group including to very high category, while data mastery of science concept in group control including to medium category. Based on analysis gained $t_{\text {count }}=7,402$ and $t_{\text {table }}=2,021$. That means there were difference of mastery of science concept between students who had been taught with group investigation learning model based with lesson study and students with conventional learning in the fifth-grade students Cluster XIV District of Buleleng in academic year 2017/2018.
\end{abstract}

Keywords: group investigation, mastery concept, science 


\section{Pendahuluan}

Salah satu cara untuk meningkatkan kesejahteraan diri adalah melalui Pendidikan. Melalui pendidikan seseorang akan memiliki kemampuan untuk menanggapi permasalahan dan memandang peristiwa-peristiwa disekitar dengan lebih baik. Pengertian pendidikan tercantum pada pasal 1 butir 1 UU No. 23 Tahun 2003 menyatakanpembelajaran adalah usaha sadar dan terencana untuk mengembangkan potensi yang dimiliki oleh peserta didik. Proses pembelajaran yang merupakan bagian dari pendidikan haruslah berjalan dengan optimal, karena kegiatan pembelajaran mempertemukan pendidik dengan peserta didik (Rahayu dan Nuryata, 2013). Pertemuan pendidik dengan peserta didik dalam sebuah pembelajaran bukanlah tanpa tujuan, tetapi telah dirancang sedemikian rupa oleh pendidik agar perserta didik mencapai kompetensi-kompetensi yang diperlukan atau ditetapkan. Proses pembelajaran yang baik menurut Pasal 19 butir 1 PP No. 19 tahun 2005 tentang SNP adalah pembelajaran yang bersifat interaktif, menyenangkan, menantang, memotivasi serta melibatkan partisipasi aktif siswa secara fisik maupun psikologis.

Riyanto (2010) menilai, sebuah pembelajaran dinyatakan berhasil apabila guru mampu mendorong siswa untuk menggunakan kognitifnya dalam melakukan pembelajaran. Melihat definisi pembelajaran dan pernyataan Riyanto, hal penting yang harus diperhatikan dalam kegiatan pembelajaran adalah adanya keterlibatan secara aktif dan kemauan dari peserta didik untuk memperoleh pengetahuannya.

Pelaksanaan proses pembelajaran seperti yang telah dijelaskan hendaknya diterapkan pada seluruh mata pelajaran yang ada, khususnya IPA. IPA sebagai ilmu yang mempelajari tentang gejala-gejala alam (Riastini, 2016), akan mempermudah siswa untuk mengenal dan menyikapi segala gejala maupun peristiwa yang terjadi di alam. Pada hakekatnya IPA digolongkan menjadi 2, yaitu IPA sebagai produk dan IPA sebagai proses (Widiana, 2016). IPA sebagai produk, merupakan sekumpulan pengetahuan dan sekumpulan konsep (Widiana, 2016). Sedangkan menurut Trianto (dalam Widiana, 2016:855), IPA sebagai proses merupakan cara yang dipergunakan untuk mempelajari objek studi, menemukan dan membangun produkproduk sains, dan sebagai aplikasi, teori-teori IPA akan melahirkan teknologi yang dapat memberi kemudahan bagi kehidupan. Pada jenjang sekolah dasar, penguasaan peserta didik terhadap IPA sebagai produk adalah hal utama yang harus dikuasai, karena konsep menjadi dasar bagi siswa untuk dapat menggolongkan fakta-fakta yang ada disekitarnya sesuai dengan ciri tertentu (Susanto, dalam Riastini, 2016:5). Hal ini akan membantu siswa untuk memahami secara mendalam gejala alam tertentu, sehingga siswa dapat memberikan respon yang tepat terhadap gejala alam tersebut. Melalui penguasaan konsep yang baik, siswa akan mampu mengaplikasikan pengetahuan yang dimilikinya dalam kehidupan sehari-hari

Pemerintah sebagai penyelenggara suatu sistem terus berusaha untuk meningkatkan mutu pendidikan sesuai standar yang ada.. Bentuk kesungguhan pemerintah pusat untuk menangani permasalahan pendidikan dan mengatur sistem pendidikan menjadi lebih baik adalah tercetusnya UU No. 23 tahun 2003 tentang Sisdiknas yang berisi segala hal-hal tentang pendidikan, baik sistem pembelajaran, tenaga kependidikan, sekolah, dan aspek-aspek lain yang menunjang terciptanya sistem pendidikan yang optimal. Hal lain yang dilakukan pemerintah dalam meningkatkan mutu pendidikan adalah dengan mengeluarkan dua kebijakan baru dalam program sertifikasi guru pada tahun 2016 yang berisikan tentang peningkatan batas nilai syarat kelulusan sertifikasi dari minimal 42 (sudah lulus) menjadi minimal 80 dan ketentuan dapat mengulang ujian sertifikasi bagi guru yang tidak lulus ujian (Maulipaksi, 2016). Peningkatan kriteria kelulusan ini, dilakukan untuk meningkatkan kompetensi tenaga pendidik dengan harapan nantinya proses pembelajaran akan lebih baik. Selain pemerintah pusat, pemerintah daerah bekerja sama dengan dinas-dinas terkait melakukan usaha perbaikan pendidikan didaerahnya. Salah satunya adalah pengadaan workshop, pelatihan-pelatihan serta seminar tentang pengembangan proses pembelajaran yang inovatif dan sesuai dengan standar proses pendidikan nasional.

Namun berdasarkan pada hasil pencatatan dokumen diketahui bahwa rata-rata skor mata pelajaran IPA siswa kelas IV di SD Gugus XIV Kecamatan Buleleng masing berada di bawah kriteria ketuntasan minimal (KKM). Hal ini menunjukkan masih kurangnya penguasaan konsep IPA pada siswa. Selanjutnya, berdasarkan hasil pengamatan yang dilakukan diketahui bahwa guru-guru di lingkungan SD Gugus XIV Kecamatan Buleleng masih menerapkan proses belajar yang terpusat pada guru. Kegiatan lain seperti mengamati lingkungan, mencoba, menganalisis, menyimpulkan, presentasi, dan mencipta belum terlihat dalam pembelajran. Pembelajaran cenderung diisi dengan kegiatan ceramah dan pemberian tugas. Padahal, 
penguasaan sebuah konsep memerlukan proses asimilasi dan akomodasi yang berkelanjutan (Sani, 2016). Suwatra, dkk (2015) menjelaskan asimilasi sebagai proses perpaduan antara pengetahuan baru dan struktur kognitif yang telah dimiliki, sedangkan akomodasi adalah penyesuaian struktur kognitif ke dalam situasi baru (Sani, 2016). Pendapat di atas menunjukkan bahwa struktur kognitif berpengaruh pada penguasaan siswa akan suatu konsep. Tingkatan kognitif individu dibagi menjadi 6 jenjang, antara lain mengingat (C1), memahami (C2), menerapkan (C3), menganalisis (C4), mengevaluasi (C5), dan mencipta (C6). Soal yang masih terbatas pada hafalan dan pemahaman hanya mencakup tingkatan mengingat (C1) dan pemahaman (C2) atau tergolong masih pada tingkat kognitif rendah. Merujuk pada data hasil pencatatan dokumen dan hasil pengamatan bahwa penguasaan konsep IPA siswa sekolah dasar masih rendah dikarenakan cara belajar yang tetap berpusat pada guru.

Berdasarkan wawancara yang dilakukan bersama seluruh guru kelas IV yang mengajar di SD Gugus XIV Kecamatan Buleleng mengungkapkan pembelajaran teacher center masih digemari karena para guru di sekolah beranggapan bahwa pembelajaran teacher center mempermudah para guru untuk menyampaikan semua isi materi dengan tuntas dan lebih cepat. Melihat permasalahan yang terjadi, maka para guru perlu bekerja sama dengan guru lain untuk menemukan dan rancangan pembelajaran yang baik bagi penguasaan konsep IPA siswa.

Salah satu cara yang dapat dilakukan adalah melalui lesson study. Lesson study adalah penyelidikan oleh sekelompok guru terhadap pembelajaran guna menciptakan pembelajaran yang mampu meningkatkan kemampuan mengajar guru secara berkelanjutan. Secara sederhana, Susanto (2012) menjabarkan tahapan lesson study menjadi 3 bagian, yaitu perencanaan (plan), implementasi (do), dan refleksi (see). Setiap tahapan tersebut dilaksanakan oleh sekelompok guru secara kolaboratif, sehingga guru akan memperoleh banyak pendapat-pendapat yang berasal dari guru lain dengan pengalaman-pengalaman berbeda. Takahashi dan Yoshida (2004) mengungkapkan bahwa lesson study memberikan kesempatan bagi guru untuk memahami gagasan pendidikan melalui praktek mengajarnya, merubah pandangan tentang cara mengajar, melihat pembelajaran dari sudut pandang siswa ,dan mendapatkan dukungan dari teman sebaya.

Selanjutnya, melalui lesson study guru harus mampu menemukan dan merancang pembelajaran yang mampu untuk meningkatkan penguasaan konsep IPA siswa. Merujuk pada hasil pengamatan menunjukkan belum tampaknya kegiatan mengamati, mencoba, membandingkan, menganalisis, dan mencipta. Sedangkan ketercapaian siswa terhadap penguasaan konsep IPA akan optimal jika siswa mendapatkan kesempatan untuk menyatukan pengetahuan baru dengan pengetahuan yang dimiliki (Rimadani, dkk, 2016). IPA juga harus diajarkan dengan pembelajaran yang memungkinkan siswa untuk membangun konsep secara mandiri melalui keterlibatannya dalam pembelajaran (Rizal, 2014). Mengacu pernyataan tersebut maka model pembelajaran yang tepat digunakan adalah model pembelajaran kooperatif group investigation. Model pembelajaran group investigation menekankan pada aktivitas siswa untuk menemukan sendiri informasi pelajaran melalui lingkungan sekitarnya atau alat-alat yang tersedia (Susilo, dkk., 2016). Hal tersebut kemudian didukung oleh hasil penelitian Paramitha, dkk (2017:9) yang menyimpulkan jika pengetahuan IPA siswa yang dibelajarkan model pembelajaran kooperatif tipe group investigation lebih tinggi dibandingkan siswa yang dibelajarkan pembelajaran konvensional. Berdasarkan permasalahan yang terjadi pada pembelajaran di kelas dan hasil penelitian yang telah disampaikan sebelumnya, maka dilakukanlah penelitian dengan judul "pengaruh model pembelajaran kooperatif group investigation berbasis lesson study terhadap penguasaan konsep IPA siswa kelas IV Semester II SD Gugus XIV Kecamatan Buleleng".

Widiarsa (2014) Temuan dalam penelitian ini memberikan petunjuk bahwa model pembelajaran group investigation memiliki keunggulan komparatif dibandingkan dengan model pembelajaran konvensional dalam hal meningkatkan motivasi belajar. Berdasarkan hal tersebut maka implikasi yang dapat diberikan adalah untuk mencapai pemahaman mengenai pengetahuan Biologi secara mendalam dan pemahaman konsep secara optimal serta meningkatkan motivasi belajar. Hal ini sejalan dengan Hartoto (2016) yang mengungkap Keuntungan bagi peserta didik dengan digunakannya model pembelajaran kooperatif tipe GI antara lain adalah Peserta didik dapat bekerja secara bebas dalam proses belajar. Peserta didik dapat belajar untuk memecahkan dan menangani suatu masalah. Dapat memberi semangat untuk berinisiatif, kreatif, dan aktif. Meningkatkan belajar bekerja sama. Belajar menghargai pendapat orang lain. Meningkatkan partisipasi dalam membuat suatu keputusan dan Peserta didik terlatih untuk mempertanggungjawabkan jawaban yang disampaikannya. 
Astri (2017) model pembelajaran kooperatif tipe Group Investigation dirancang untuk membawa siswa secara langsung ke dalam proses ilmiah melalui investigasi kelompok siswa terhadap materi yang diajarkan dan percobaan yang dilakukan secara langsung yang dimana mereka saling berinteraksi dalam mendiskusikan dan menganalisis hasil penyelidikan terhadap percobaan yang telah dilakukan dan kemudian mendapatkan informasi baru dan kesimpulan dari pembelajaran yang berlangsung. Model pembelajaran ini benar-benar mengajak siswa menjadi aktif.

Penelitian ini bertujuan untuk mengetahui mengetahui perbedaan penguasaan konsep IPA antara siswa kelas IV semester II yang menerapkan model pembelajaran kooperatif group investigation berbasis lesson study dengan siswa kelas IV semester II yang menerapkan pembelajaran konvensional di SD Gugus XIV Kecamatan Buleleng.

\section{Metode}

Jenis penelitian ini adalah eksperimen semu (quasi experiment). Rancangan penelitian ini menggunakan non-equivalent post test only control group design. Tempat pelaksanaan penelitian ini adalah di Gugus XIV Kecamatan Buleleng pada semester II tahun pelajaran 2017/2018. Kelompok eksperimen diberikan perlakuan yaitu dibelajarkan model pembelajaran kooperatif tipe group investigation berbasis lesson study, sedangkan kelompok kontrol dibelajarkan pembelajaran konvensional.

Populasi pada penelitian ini adalah siswa kelas IV SD di Gugus XIV Kecamatan Buleleng tahun 2017/2018 yang dibelajarkan kurikulum satuan tingkat pendidikan (KTSP) dan kurikulum 2013 dengan jumlah keseluruhan 144 siswa yang tebagi ke dalam 5 kelas.Selanjutnya dilakukan uji kesetaraan untuk mengetahui kesetaraan kemampuan akademik kelas IV SD di Gugus XIV Kecamatan Buleleng. Penelitian ini hanya melibatkan SD yang menggunakan KTSP, sehingga yang menjadi sampel pada penelitian adalah SDN 2 Tukadmungga dan SDN 2 Pemaron. Hasil ini kemudian diundi kembali untuk menentukan kelas eksperimen dan kelas kontrol. berdasarkan pengundian diketahui, SDN 2 Tukadmungga sebagai kelas eksperimen dan SDN 2 Pemaron sebagai kelas kontrol.

Data yang dikumpulkan dalam penelitian ini adalah penguasaan konsep IPA kelas IV. Metode yang digunakan untuk mengumpulkan data penguasaan konsep IPA adalah tes pilihan ganda dengan jumlah soal 30 butir.Sebelum digunakan, perangkat tes akan di uji untuk mengetahui kelayakan perangkat tes secara keseluruhan maupun perbutir.

Analisis dalam penelitian melibatkan analisis deskriptif dananalisis inferensial. Analisis deskriptifmemiliki tujuan untuk mengetahui tinggi maupun rendahnya data penguasaan IPA siswa kelas IV pada kelompok kontrol maupun kelompok eksperimen. Pada analisis deskriptif diperoleh hasil mean, median, modus, standar deviasi, dan varians. Sedangkan, uji inferensial meliputi uji prasyarat hipotesis dan uji hipotesis.Adapun yang termasuk uji prasyarat antara lain, uji normalitas sebaran data dan uji homogenitas varians. Uji hipotesis pada penelitian ini menggunakan uji-t untuk mengetahui ada atau tidaknya perbedaan pada kelompok eksperimen dan kelompok kontrol penelitian. Rumus uji-t yang digunakan adalah polled varians. Pemilihan rumus ini didasarkan pada ketentuan $\mathrm{n}_{1} \neq \mathrm{n}_{2}$, data berdistribusi normal, dan varians homogen.

\section{Hasil dan Pembahasan}

Hasil analisis deskriptif seperti mean (M), median (Me), modus (Mo), standar deviasi (SD), dan varians data $\left(\mathrm{SD}^{2}\right)$ penguasaan konsep IPAsiswa kelas IV kelompok eksperimen dan kelompok kontrol telah disajikan secara lengkap pada Tabel 1.

Tabel 1. Deskripsi Data Penguasaan IPA Kelompok Eksperimen dan Kelompok Kontrol

\begin{tabular}{ccc}
\hline Statistik & Kelompok Eksperimen & Kelompok kontrol \\
\hline Mean (M) & 22,71 & 13,92 \\
Median (Me) & 23,71 & 13,60 \\
Modus (Mo) & 24,63 & 13,35 \\
Standar Deviasi & 3,93 & 3,62 \\
Varians & 15,42 & 3,62 \\
\hline
\end{tabular}

Berdasarkan Tabel 1, kemudian disusun kurva poligon kelompok eksperimen dan kelompok kontrol. Kurva poligon kelompok eksperimen dapat dilihat pada Gambar 1. 


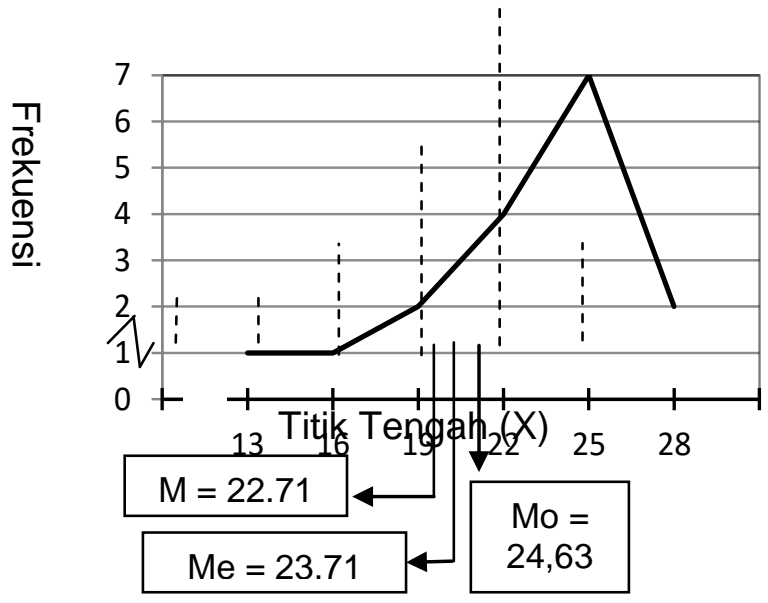

\section{Gambar 1. Kurva Poligon Penguasaan Konsep IPA Kelompok Eksperimen}

Mengacu pada kurva poligon pada Gambar 1, diketahui bahwa modus memiliki nilai lebih besar dari median dan median memiliki nilai lebih besar daripada mean $(24,63>23,71>23,71)$. Berdasarkan hal tersebut, diketahui bahwa sebagian besar skor penguasaan konsep IPA yang diperoleh kelompok eksperimen cenderung tinggi.Kemudian data penguasaan konsep IPA dikonversikan dengan kriteria penilaian untuk mengetahi kualitas variabel penguasaan konsep IPA.Setelah dilakukan konversi diperoleh hasil bahwa rata-rata penguasaan konsep IPA kelompok eksperimen termasuk kategori sangat tinggi. Gambar 2.

Distribusi frekuensi data penguasaan konsep IPA kelompok kontrol telah disajikan pada

\section{Distribusi kelopmpok}

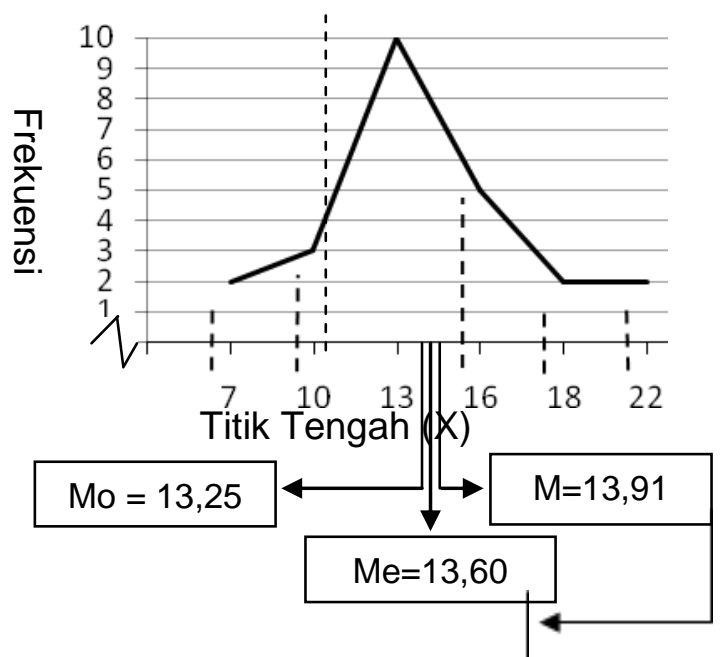

Gambar 2. Kurva Poligon Penguasaan Konsep IPA Kelompok Kontrol

Mengacu pada kurva poligon pada Gambar 2, diketahui bahwa modus memiliki nilai lebih kecil dari median dan median memiliki nilai lebih kecil daripada mean $(13,25<13,60<13,91)$. Berdasarkan Gambar 2. menunjukkan bahwa sebagian besar skor penguasaan konsep IPA yang diperoleh kelompok eksperimen cenderung rendah. Setelah dilakukan konversi diperoleh hasil bahwa rata-rata penguasaan konsep IPA kelompok eksperimen termasuk kategori sedang.

Uji normalitas sebaran data kelompok eksperimen diperoleh harga $t_{\text {hitung }}=3,861$ dan kelompok kontrol diperoleh $t_{\text {hitung }}=4,555$ dengan diketahuit tabel $=7,815$. Berdasarkan hasil tersebut diketahui bahwa $t_{\text {hitung }}$ kelompok eksperimen dan kelompok kontrol lebih kecil dari $t_{\text {tabel }}$. Selanjutnya hasil analisis homogenitas varian menunjukkan harga $F_{\text {hitung }}=1,180$ dengan $F_{\text {tabel }}=$ 4,08. Hasil ini menunjukkan $F_{\text {hitung }}<F_{\text {tabel }}$, sehingga dapat diketahui bahwa varians telah homogen. Hasil uji analisis hipotesis menunjukkan $t_{\text {hitung }}=7,402$ dengan harga $t_{\text {tabel }}=2,021$. Hasil ini menunjukkan bahwa $t_{\text {hitung }}>t_{\text {tabel }}(7,402>2,021)$, sehingga dapat diketahui bahwa 
terdapat perbedaan penguasaan konsep IPA antara siswa kelas IV semester II yang menerapkan model pembelajaran kooperatif group investigationberbasis lesson study dengan siswa kelas IV semester II yang menerapkan pembelajaran konvensional di SD Gugus XIV Kecamatan Buleleng.

Perbedaan penguasaan konsep IPA antara kelompok eksperimen dan kelompok kontrol disebabkan langkah-langkah model pembelajaran kooperatif tipe group investigation melibatkan seluruh siswa untuk berpartisipasi aktif, seperti mengamati, mencoba, dan membentuk pengetahuannnya secara mandiri, sehingga tercapainya penguasaan konsep tertentu pada mata pelajaran IPA.

Tahap pertama, model pembelajaran kooperatif tipe group investigation adalah grouping. Grouping yaitu membentuk siswa ke dalam beberapa kelompok yang heterogen. Slavin (dalam Wati, S.R., dkk. 2018:4) menjelaskan bahwa kelompok adalah salah satu metode untuk mendorong keterlibatan maksimal para siswa. Hal ini tercermin dari proses pembentukan kelompok. Seluruh siswa antusias untuk bergerak mencari anggota kelompok maupun saat mengatur meja dan kursi. Pemahaman siswa terhadap konsep bekerja secara kelompok terwujud dalam kemampuan siswa untuk melaksanakan tugas-tugas kelompok dengan mengutamakan kerjasama sebagai kelompok. Kemampuan siswa menerapkan konsep kerja kelompok, secara tidak langsung mengembangkan dimensi kognitif siswa pada ranah C3 yang menuntut siswa untuk mampu manerapkan konsep yang dikuasainya (Kosasih, 2016). Yusuf, dkk (2013) menyatakan perkembangan kognitif memengaruhi kemampuan seseorang untuk mengingat dan memanipulasi informasi, sehingga perkembangan kognitif menjadi faktor pendukung tercapainya penguasaan konsep. Keterlibatan yang terjadi pada sebagian besar siswa tahap grouping mencirikan adanya minat siswa untuk belajar. Temuan ini sejalan dengan hasil penelitian Gusniwati (2015) yang mengungkapkan jika penguasaan konsep matematika siswa akan lebih efektif dengan cara meningkatkan minat belajarnya.

Tahap kedua, model pembelajaran kooperatif tipe group investigation adalah planning. Pada tahap planning, siswa aktif untuk menentukan langkah-langkah yang akan dilakukan dalam memecahkan permasalahan, menentukan sumber-sumber pendukung, dan menentukan tugas masing-masing anggota kelompok. Hal ini tampak pada pembelajaran saat guru telah menyampaikan topik-topik yang akan dibahas dan pembagian media kepada siswa. Seluruh siswa terlihat berdiskusi mengenai pembagian tugas dan langkah-langkah yang harus dilakukan agar mendapatkan informasi yang tepat tentang topik yang dibahas. Perilaku ini menunjukkan terjadinya kerjasama dan interaksi antar siswa dalam kelompok dan yang merupakan salah satu kelebihan dari model pembelajaran kooperatif tipe group investigation (Kurniasih dan Sani, 2016). Hal ini sejalan dengan temuan Artini, dkk (2016) yang mengungkapkan bahwa kerjasama, memberikan kontribusi terhadap pengalaman belajar, sehingga siswa memiliki pengetahuan yang memadai setelah diberikan tes akhir. Memberikan kebebasan pada siswa untuk menentukan caranya sendiri memahami dan membentuk sebuah konsep adalah salah satu cara untuk menumbuhkan penguasaan konsep pada siswa dan konsep yang dibentuk bersifat long-term memory (Ariawan, dkk. 2016). Kegiatan planning melatih siswa untuk memutuskan langkah-langkah yang perlu dan tepat untuk dilakukan dan menyusun keputusankeputusan tersebut menjadi posedur penyelidikan yang sistematis. Memutuskan akan mengembangkan dimensi kognitif pada ranah C5 yaitu mengevaluasi, sedangkan kegiatan menyusun akan mengembangkan siswa pada ranah $\mathrm{C} 2$, yaitu memahami.

Tahap ketiga adalah investigation, pada tahap ini siswa mulai aktif mengumpulkan informasi berkenaan tentang topik dari berbagai sumber dengan cara yang telah ditentukan bersama pada tahap planning. Pemerolehan informasi yang terjadi saat pembelajaran tidak hanya terpaku pada sumber-sumber cetak, seperti buku. Pada pembelajaran yang telah dilakukan, seluruh siswa sangat tertarik untuk mengamati dan mencoba media-media yang dilibatkan dalam pembelajaran. Banyak siswa mencatat temuan-temuannya selama membaca buku, mengamati, dan mencoba media. Cobb (dalam Kandeel, 2016:83) menyatakan konsep dibangun melalui interaksi langsung dengan keadaan sekitar. Pernyataan ini, menunjukkan pentingnya melibatkan siswa dengan lingkungannya dalam upaya mencapai penguasaan konsep. Pernyataan ini sejalan dengan temuan Aditya (2016) yaitu perlunya melibatkan alam semesta dalam sebuah pembelajaran demi meningkatkan pengetahuan siswa. Tahap Investigation melatih siswa untuk menemukan dan mencatat informasi-informasi penting di dalam sebuah peritiwa atau kejadian. Menemukan merupakan kegiatan yang akan mengembangkan dimensi kognitif siswa pada ranah $\mathrm{C} 4$, yaitu menganalisis dan mencatat mengembangkan siswa pada ranah $\mathrm{C} 1$, yaitu mengingat. 
Tahap keempat adalah organizing, pada tahap ini siswa mendiskusikan hasil penyelidikan terhadap suatu topik dari berbagai sumber dan cara yang telah ditentukan dan menentukan cara menyampaika hasil penyelidikannya pada tahap presenting. Saat pembelajaran berlangsung, sebagian besar siswa sangat antusias untuk mengemukakan pendapatnya. Berdiskusi berjalan baik, tanpa dominasi satu atau dua orang pada tiap kelompok. Melalui diskusi siswa, mampu membangun penguasaan konsep IPAnya. Hal ini dikarenakan diskusi membantu siswa untuk mendapatkan berbagai perspektif baru terhadap sebuah permasalahan, sehingga siswa mampu memperbaiki dan mengembangkan penafsirannya terhadap suatu masalah (Borich, 2014). Pada tahap organizing, siswa melatih diri untuk mengemukakan, menanggapi pendapat, menunjukkan kelebihan maupun kekurangan, mengaitkan, dan menyimpulkan berbagai pendapat. Mengemukakan pendapat merupakan pengembangan dimensi kognitif siswa pada ranah C2, yaitu memahami. Menanggapi dan menunjukkan kelebihan atau kekurangan mengembangkan dimensi kognitif siswa pada ranah C5 yaitu mengevaluasi, sedangkan mengaitkan mengembangkan ranah kognitif C3, yaitu menerapkan dan hal yang terakhir adalah menyimpulkan. Menyimpulkan mengembangkan dimensi kognitif siswa pada ranah $\mathrm{C} 4$, yaitu menganalisis.

Tahap kelima adalah presenting. Pada tahap presenting masing-masing perwakilan kelompok menyampaikan hasil diskusinya di depan kelas. Melalui presenting siswa mendapatkan kesempatan untuk berbagi pengetahuan yang telah dimilikinya dengan kata lain siswa telah belajar untuk mengajarkan pengetahuannya kepada orang lain. Saat pembelajaran berlangsung, sebagian besar siswa mampu untuk menyampaikan hasil penyelidikannya dengan baik. Hal ini ditunjukkan oleh kepercayaan diri sebagian besar siswa saat dipilih untuk maju menyampaikan hasil penyelidikannya. Siberman (dalam Riastini, 2016:47) mengungkapkan beberapa hal tentang paham belajar aktif yang salah satunya berbunyi what I teach to another, I master (apa yang saya ajarkan pada orang lain, saya menguasainya). Hal ini menunjukkan jika siswa telah mampu mengomunikasikan pengetahuan yang dimiliki dengan baik dan dapat dimengerti oleh temannya, maka siswa tersebut dapat dikatakan telah menguasai pengetahuan tersebut termasuk konsep-konsep di dalamnya. Tahap presenting melatih siswa untuk mengingat kembali pengetahuan yang ia miliki, sehingga mengembangkan dimensi kognitif pada ranah $\mathrm{C} 1$, yaitu mengingat Pada tahap ketujuh atau terakhir adalah evaluating. Pada tahap ini guru memiliki peranan penting untuk meluruskan dan memperbaiki konsep-konsep keliru yang dimiliki siswa. Setelah itu, guru melakukan tes untuk mengetahui ketercapaian siswa untuk menguasai materi dan konsep-konsep yang dipelajari.

Berdasarkan temuan-temuan pada kelompok eksperimen, dapat diketahui bahwa model pembelajaran kooperatif tipe group investigation memiliki keunggulan yang mampu memberikan pengaruh positif bagi pembelajaran, sehingga tepat untuk diterapkan dalam pembelajaran. Keunggulan yang dimiliki model pembelajaran kooperatif tipe groupinvestigation adalah 1) pembelajaran berpusat pada siswa, sehingga siswa memiliki kebebasan untuk mencari, membentuk, dan mengembangkan konsep sesuai kemampuannya, 2) sintaks yang terdapat pada model pembelajaran kooperatif tipe group investigation membantu siswa untuk menguasai konsep-konsep tertentu, dan 3) mengembangkan interaksi, kerjasama, dan keterlibatan siswa dalam pembelajaran. Beberapa hal ini menjadikan model kooperatif tipe groupinvestigation lebih unggul dibandingkan dengan pembelajaran konvensional. Pembelajaran konvensional merupakan pembelajaran yang bersifat teacher center, sehingga pembelajaran lebih didominasi oleh guru sedangkan siswa hanya menerima secara pasif. Ketiadaan interaksi multi arah pada pembelajaran konvensional menyebabkan terhambatnya pembentukan konsep pada siswa. Adapun tahap-tahap pembelajaran konvensional adalah 1) guru menyampaikan tujuan pembelajaran, 2) guru memberikan informasi tentang materi kepada siswa, 3) tanya jawab, 4) penugasan, dan 5) guru menyimpulkan hasil belajar. Berdasarkan tahap-tahap tersebut, dapat diketahui bahwa pembelajaran konvensional tidak memberikan ruang bagi siswa untuk menggali dan membentuk sebuah informasi sesuai kemampuannya, sehingga sulitnya siswa untuk menguasai konsep yang diberikan oleh guru.

Selain keunggulan model pembelajaran kooperatif tipe group investigation, hal yang ikut berperan penting yang menyebabkan perbedaan penguasaan kelompok eksperimen dan kontrol adalah lesson study. Lesson study memberikan kesempatan pada guru untuk melakukan perbaikan cara mengajar di kelas sesuai masukan dan pendapat kelompok guru yang terlibat (Vlorensius, dkk. 2016). Pada penelitian ini, lesson study jadi dasar berpikir pada kegiatan perencanaan pembelajaran, pelaksanaan pembelajaran, dan setelah pembelajaran, sesuai dengan tahapan lesson study yaitu, plan, do, dan see. 
Pada tahap plan, kelompok lesson study yang beranggotakan guru kelas IV, kepala sekolah dan pihak-pihak lain, mendiskusikan rancangan RPP yang akan digunakan dalam pembelajaran. Pada penelitian ini, model pembelajaran telah ditentukan yaitu model pembelajaran kooperatif tipe group investigation, sehingga diskusi lebih difokuskan pada hal-hal yang perlu ditingkatkan dari model pembelajaran kooperatif tipe group investigation agar sesuai dengan kebutuhan siswa. Diskusi ini bertujuan untuk membentuk model kooperatif tipe group investigation yang mampu meningkatkan penguasaan konsep IPA siswa.

Pada tahap do, dilaksanakan open class yang melibatkan beberapa pihak sebagai observer. Menurut Hart, dkk (2011) lesson study lebih berfokus pada siswa, sehingga perilaku dan reaksi siswa dalam mengikuti proses pembelajaran menjadi hal yang harus diperhatikan. Oleh sebab itu,observer bertugas untuk mengamati reaksi siswa saat dibelajarkan menggunakan model pembelajaran kooperatif tipe group investigation.

Pada tahap see, para observer melakukan diskusi bersama guru model tentang reaksi siswa terhadap model pembelajaran kooperatif tipe group investigation yang dibelajarkan sebelumnya. Melalui diskusi, guru model mengetahui beberapa siswa tidak mengikuti pembelajaran dengan baik. Hasil ini akan menjadi acuan untuk mengembangkan model pembelajaran kooperatif tipe group investigation agar mampu mengembangkan penguasaan konsep siswa. Adanya perbaikan ini menyebabkan adanya peningkatan terhadap cara mengajar guru di kelas. Prinsip lesson study yang mengutamakan kolaboratif membantu para guru untuk menemukan kekurangan-kekurangan yang belum disadari.. Oleh karena itu, Takahashi dan Yoshida (2004) mengungkapkan bahwa lesson study memberikan guru kesempatan untuk melihat praktik mengajar mereka dari perspektif siswa. Semakin paham guru mengenai kebutuhan siswa dalam proses belajar, maka guru akan mampu menentukan cara terbaik untuk mencapai tujuan belajar yang telah ditentukan (Abizar, 2017).

Hasil penelitian ini sesuai dengan hasil penelitian yang dilakukan oleh Artini, dkk (2016) yang mengungkapkan bahwa menunjukkan model pembelajaran kooperatif tipe group investigation dapat meningkatkan aktivitas dan hasil belajar IPA siswa. Penelitian lain yang memperoleh hasil serupa adalah penelitian yang dilakukan oleh R. Ricko Candra Aditya (2016) yang menyatakan pembelajaran IPA menggunakan model pembelajaran kooperatif tipe group investigation menghasilkan peningkatan aktivitas dan hasil belajar IPA siswa.

Berdasarkan temuan-temuan pada penelitian ini, dapat dinyatakan bahwa model pembelajaran kooperatif tipe group investigation berbasis lesson study berpengaruh terhadap penguasaan konsep IPA siswa kelas IV semester II di SD Gugus XIV Kecamatan Buleleng tahun pelajaran 2017/2018.

\section{Simpulan dan Saran}

Berdasarkan pada hasil analisis data dapat disimpulkan bahwa terdapat perbedaan penguasaan konsep IPA antara kelompok siswa yang dibelajarkan model pembelajaran kooperatif tipe group investigation berbasis lesson study dan kelompok siswa yang dibelajarkan pembelajaran konvensional pada siswa kelas IV semester II di SD Gugus XIV Kecamatan Buleleng tahun pelajaran 2017/2018.

Berdasarkan hasil penelitian pengalaman yang diperoleh selama melakukan penelitian, maka disarankan; (1) kepada guru untuk menggunakan model pembelajaran kooperatif tipe group investigation pada pembelajaran IPA maupun mata pelajaran lainnya. Selain itu guru diharapkan memperhatikan pembagian kelompok agar terciptanya kelompok yang heterogen dan memperhatikan variasi tempat serta media yang terlibat pada penyelidikan agar tidak terjadi kebosanan, (2) kepada kepala sekolah untuk ikut memberikan dukungan dan motivasi pada guru-guru untuk menerapkan model pembelajaran kooperatif group investigation dalam pembelajaran di kelas, dan (3) kepada peneliti lain, untuk mengembangkan model pembelajaran kooperatif tipe group investigation, sehingga akan menambah referensi dalam kajian-kajian ilmiah dan pengetahuan pada bidang pendidikan khususnya pengetahuan tentang model-model pembelajaran. 


\section{Daftar Pustaka}

Abizar, H. 2017. Buku Master Lesson Study. Yogyakarta: Diva Press.

Aditya, R. R. Candra. 2016. "Peningkatan Aktivitas Dan Hasil Belajar IPA Melalui Model Pembelajaran Kooperatif Tipe Group Investigation Pada Siswa Kelas V SD Negeri 1 Sungapan”. Jurnal Pendidikan Guru Sekolah Dasar, Edisi-38, Tahun ke-5 (3.623-3.633)

Ariawan, K. D., dkk. 2016. "Pengaruh Model Pembelajaran Kooperatif Tipe Group Investigation Berbasis Media Lingkungan Terhadap Hasil Belajar IPA Siswa Kelas IV di Desa Sidetapa". E-Journal PGSD Universitas Pendidikan Ganesha, Volume 4, Nomor 1 (hlm $1-10)$.

Artini, dkk. 2016. "Penerapan Model Pembelajaran Kooperatif Tipe Group Investigation untuk Meningkatkan Aktivitas dan Hasil Belajar IPA Pada Siswa Kelas VI SD Inpres 1 Tondo". e-Journal Mitra Sains, Volume 4, Nomor 1 (hlm 76-83).

Astri Ria. 2017. Pembelajaran Kooperatif Tipe Group Investigation (GI) Dengan Metode KnowWant-Learn (KWL): Dampakterhadap Hasil Belajar Fluida Dinamis. Jurnal IImiah Pendidikan Fisika Al-BiRuNi 06 (2) (2017) 149-158

Borich, G. D. 2014. Effective Teaching Methods: Research-Based Practice Eight Edition. United States of America: Pearson.

Gusniwati, M. 2015. "Pengaruh Kecerdasan Emosional Dan Minat Belajar Terhadap Penguasaan Konsep Matematika Siswa Sman Di Kecamatan Kebon Jeruk". Jurnal Formatif, Volume 5, Nomor 1 (hlm 26-41).

Hart, L., dkk. 2011. Lesson Study Research and Practice in Mathematics Education. California: Springer. Tersedia pada https://doi.org/10.1007/978-90-481-9941-9. Diunduh pada 15 Desember 2017

Hartoto Tri. 2016. Model Pembelajaran Kooperatif Tipe Group Investigation (Gl) Meningkatkan Aktivitas Dan Hasil Belajar Sejarah. Jurnal HISTORIA Volume 4, Nomor 2, Tahun 2016

Kandeel, R. A. A. 2016. "Basic Education Teachers Proficiency of Skills Required for Teaching Mathematical Concepts". Journal of Education and Practice, Volume 7, Nomor 29 (hlm 83-91).

Kosasih, E. 2016. Strategi Belajar dan Pembelajaran Implementasi Kurikulum 2013. Bandung: Yrama Widya.

Kurniasih, I. dan B. Sani. 2016. Ragam Pengembangan Model Pembelajarn untuk Meningkatkan Profesionalitas Guru. Jakarta: Kata Pena.

Maulipaksi, D. 2016. "Dua Kebijakan Baru dalam Program Sertifikasi Guru Tahun 2016". Tersedia pada https://www.kemdikbud.go.id. Diakses pada tanggal 09 Desember 2017.

Paramitha, A. A. R., dkk. 2017. "Pengaruh Model Pembelajaran Kooperatif Tipe Group Investigation Berbantuan Lingkungan Terhadap Kompetensi Pengetahuan IPA Siswa Kelas V SD Gugus Kompyang Sujana Denpasar Utara Tahun Ajaran 2016/2017". EJournal PGSD Universitas Pendidikan Ganesha, Volume 5, Nomor 2, (hlm 1-10).

Rahayu, E. S. dan I M. Nuryata. 2013. Pembelajaran Masa Kini. Jakarta: Sekarmita.

Redaksi Sinar Grafika. 2007. Standar Nasional Pendidikan: Peraturan Permerintah Republik Indonesia Nomor 19 Tahun 2005 tentang Standar Nasional Pendidikan. Jakarta: Sinar Grafika.

Riastini, P. N., dkk. 2016. Pembelajaran IPA di SD. Singaraja: Undiksha. 
Rimadani, E., dkk. 2016. "Penguasaan Konsep dan Kemampuan Pemecahan Masalah Siswa SMA pada Materi Suhu dan Kalor". Makalah ini disajikan dalam Prosiding Seminar Nasional Pendidikan IPA Pascasarjana UM. Malang: 2016

Riyanto, Y. 2010. Paradigma Baru Pembelajaran: Sebagai Referensi bagi Pendidik dalam Implementasi Pembelajaran yang Efektif dan Berkualitas. Jakarta: Prenada Media.

Rizal, M. 2014. "Pengaruh Pembelajaran Inkuiri Terbimbing dengan Multi Representasi terhadap Keterampilan Proses Sains dan Penguasaan Konsep IPA Siswa SMP". Jurnal Pendidikan Sains, Volume 2, Nomor 3 (hlm 159-165).

Sani, R. A. 2016. Inovasi Pembelajaran. Jakarta: Bumi Aksara.

Susanto, J. 2012. "Pengembangan Perangkat Pembelajaran Berbasis Lesson Study dengan Kooperatif Tipe Numbered Heads Together untuk Meningkatkan Aktivitas dan Hasil Belajar IPA di SD". Journal of Primary Educational, Volume 1, Nomor 2 (hlm 71-77).

Susilo, F., dkk. 2016. "Pembelajaran Fisika Menggunakan Model Jigsaw dan Gl (Group Investigation) Ditinjau dari Kreativitas dan Sikap IImiah Siswa". Jurnal Inkuiri, Volume 5, Nomor 3 (hlm 40-48).

Suwatra, Ign. I W., dkk. 2015. Belajar dan Pembelajaran Sekolah Dasar. Singaraja: Undiksha.

Takahashi, A., dan M. Yoshida. 2004. "Ideas for Establishing Lesson-Study Communities". Teaching Children Mathematics, Volume 10, Nomor 9 (hlm 436-443).

Vlorensius, dkk. 2016. "Persepsi dan Preferensi Guru-Guru di Kabupaten Tana Tidung Terhadap Penerapan Lesson Study Berdasarkan Motivasi dan Sikap untuk Pengembangan Profesionalisme Guru Wilayah Perbatasan". Jurnal Pendidikan Biologi Indonesia, Volume 2, Nomor 3 (hlm 277-291).

Wati, S. R., dkk. 2018. "Perbedaan Hasil Belajar Siswa SMK Antara Model Pembelajaran Kooperatif Tipe Group Investigation dengan Model Pembelajaran Problem Based Learning Pada Pokok Bahasan Larutan Elektrolit dan Nonelektrolit". Bivalen: Chemical Studies Journal, Volume 1, Nomor 1 (hlm 1-15).

Widiana, I. W. 2016. "Pengembangan Asesmen Proyek Dalam Pembelajaran IPA". Jurnal Pendidikan Indonesia, Volume 5, Nomor 2 (hlm 854-864).

Widiarsa Putu. 2014. Pengaruh Penggunaan Model Pembelajaran Kooperatif Tipe Group Investigation (Gi) Terhadap Motivasi Belajar Dan Pemahaman Konsep Biologi Siswa Sma Negeri 2 Banjar . E-Journal Program Pascasarjana Universitas Pendidikan Ganesha

Yusuf, L.N., dkk. 2013. Perkembangan Peserta Didik: Mata Kuliah Dasar Profesi (MKDP) Bagi Para Mahasiswa Calon Guru di Lembaga Pendidikan Tenaga Kependidikan (LPTK). Jakarta: Rajawali Pers. 